\title{
STRATEGI KOMUNIKASI MASYARAKAT KAMPUNG JELEKONG DALAM MEWARISKAN SENI LUKIS
}

\author{
Dinda Krisi Monika, Nela Widiastuti \\ Prodi Ilmu Komunikasi, Fakultas Komunikasi dan Desain \\ Universitas ARS Bandung, J1 Sekolah Internasional Antapani Bandung Jawa Barat \\ Email : Dinda.Krisi.Monika@gmail.com, widiastustinela@yahoo.co.id
}

\begin{abstract}
This study discusses the communication strategy carried out by the community in the inheritance of paintings related to the community's communication strategy in passing down paintings, understanding how senior painters pass down safe village paintings and find ways in the process of inheriting paintings. This research uses a qualitative method using ethnographic studies. Data collection is done by interview, collection and internet. The results of this study are the Jelekong Society bequeathed a legacy from generation to generation to protect sustainable life, bequeathed painting techniques to the younger generation, increase the interest of the younger generation in passing down painting and know how the obstacles that occur in the process of inheritance of painting in the jelekong village.
\end{abstract}

Keywords: Communication Strategy, Inheritance, Art Painting

\begin{abstract}
Abstrak
Penelitian ini bertujuan untuk mengetahui strategi komunikasi yang dilakukan masyarakat dalam upaya pewarisan seni lukis yang berfokus pada bagaimana strategi komunikasi masyarakat dalam mewariskan seni lukis mengetahui bagaimana peranan pelukis senior dalam mewariskan seni lukis kampung jelekong dan mengetahui hambatan dalam proses pewarisan seni lukis. Penelitian ini menggunakan metode kualitatif dengan pendekatan studi etnografi. Pengumpulan data dilakukan dengan wawancara, observasi dan internet. Hasil penelitian ini adalah Strategi komunikasi yang digunakan masyarakat jelekong dalam mewariskan warisan turun temurun untuk meningkatkan penjualan hasil karya lukis untuk menjaga kesinambungan hidup, mewariskan Teknik dasar melukis kepada generasi muda, meningkatkan minat generasi muda dalam mewariskan seni lukis, dan mengetahui bagaimana hambatan yang terjadi pada proses pewarisan seni lukis dikampung jelekong.
\end{abstract}

Kata kunci : Strategi Komunikasi, Pewarisan, Seni lukis 


\section{Pendahuluan}

Kampung Seni sebagai warisan berada di bawah lereng gunung yang kekayaan yang dimiliki Indonesia menjadi menjulang sebelah selatan Kota Bandung daya tarik wisata Indonesia. Keindahan kurang lebih berjarak $12 \mathrm{~km}$, yang berada alam yang masih terjaga, pemandangan yang masih asri, budaya yang kental, dan penduduk yang ramah membuat kampung seni sebagai salah satu peninggalan sejarah untuk dipertahankan pada generasi muda.

Kampung Seni menjadi tempat para seniman melakukan aktivitas membuat sebuah karya seni yang memberi manfaat kepada para pecinta seni dan juga para seniman untuk menampung hasil karya yang memiliki tujuan untuk mempertahankan budaya yang sudah temurun untuk dijadikan tempat wisata. Seni dan budaya yang ada pada kampung seni menjadi sebuah daya tarik bagi wisatawan lokal maupun mancanegara untuk mengunjungi wilayahnya sebagai desa wisata. Kesenian dan budaya yang ada di kampung seni sudah sepatutnya dilestarikan oleh masyarakat dan pemerintah setempat dengan adanya daya tarik yang tinggi menjadikan desa wisata sebagai mata pencaharian masyarakat sekitar.

Salah satu daerah kabupaten Bandung yang memiliki karakteristik kehidupan sosial budaya yang menarik adalah kampung jelekong. Kampung jelekong dikecamatan baleendah, kabupaten bandung provinsi jawa barat. Jelekong salah satu wisata pengrajin seni lukis yang sudah turun temurun.

Provinsi Jawa Barat memiliki kampung seni dan budaya yang memiliki daya tarik untuk dilestarikan tepatnya di wilayah kelurahan jelekong kabupaten bandung terdapat galeri dan sanggar seni lukis. Seni lukis jelekong memiliki keunikan dari lukisan yang dibuat diambil dari keadaan sekitar kampung jelekong yang masih alami dengan pemandangan alam.

Para pelukis jelekong berguru pada pelukis senior dan belajar secara otodidak. Hanya Sebagian orang yang mengikuti pendidikan formal dengan jurusan seni atau desain di perguruan tinggi. Namun, mereka memiliki pewarisan turun temurun yaitu seni lukis, sudah menjadi budaya di kampung seni jelekong.

Lukisan hasil karya penduduk jelekong mudah ditemui disekitar jalan kampung jelekong. Dalam hal ini budaya sangat berperan penting dalam penyampaian komunikasi terhadap masyarakat sekitar, maka harus ada 
pewarisan budaya untuk mempertahankan budaya seni lukis kampung jelekong.

Pewarisan yang dibahas dalam penelitian ini adalah bagaimana strategi komunikasi masyarakat yang dilakukan dalam pewarisan seni lukis di kampung jelekong. Dan mengetahui bagaimana peranan pelukis senior jelekong dalam pewarisan seni dan budaya kampung jelekong yang terus dipertahankan hingga saat ini, dalam pewarisan budaya yang sangat melekat di kampung seni jelekong sehingga sangat menarik untuk dijadikan sebuah penelitian.

Penelitian berfokus kepada kampung seni lukis jelekong karena seni dan budaya kampung jelekong ini menjadi salah satu potensi wisata yang ada di kabupaten bandung. Jelekong terkenal dengan hasil seni lukis yang sudah temurun, terlihat disepanjang jalan jelekong banyak sanggar dan galeri lukisan. Dari karya lukisan pelukis jelekong menjadi mata pencaharian bagi masyarakat sekitar, menjadikan pusat perekonomian warga kampung jelekong. Penelitian ini mencari dan menggali informasi mengenai pewarisan budaya seni lukis yang menjadi suatu hasil kerajinan tangan bagi masyarakat jelekong yang sudah turun temurun.
Teknik yang digunakan berupa observasi, yaitu dengan melakukan peninjauan atau penelitian lapangan. Penelitian ini menggunakan paradigma konstruktivis, yang bertujuan untuk menemukan suatu realitas berdasarkan konstruksi pewarisan seni lukis. Penelitian ini menggunakan teori pembelajaran sosial, dengan masalah penelitian mengenai strategi komunikasi dalam pewarisan seni lukis, teori pembelajaran sosial perilaku yang baru dibentuk dari mengamati dan meniru orang lain cara belajar melalui pengalaman langsung atau pengaruh lingkungan. Manusia tidak luput dari interaksi terhadap orang lain didalam lingkungan masyarakat, proses komunikasi yang terjadi dalam pewarisan seni budaya pada penyampaian kebiasaan yang sudah menjadi adat turun temurun sudah melekat kepada masyarakat dalam mewariskan hasil karya lukis kepada keluarga, masyarakat sekitar untuk mempertahankan budaya desa jelekong.

Sehubungan dengan konteks penelitian yang telah dijelaskan sebelumnya, peneliti memfokuskan penelitiannya pada bagaimana Strategi Komunikasi masyarakat jelekong dalam mewariskan budaya seni lukis. 


\section{TINJAUAN PUSTAKA}

\section{Strategi Komunikasi}

Menurut Onong Uchjana Effendy (1981) dalam buku (Edi Suryadi, 2018) Strategi komunikasi merupakan panduan dari perencanaan komunikasi (communication planning) dan manajemen (communication manajement) untuk mencapai suatu tujuan, bahwa pendekatan (approach) bisa berbeda sewaktu - waktu tergantung dari situasi dan kondisi. Strategi komunikasi terdiri dari dua aspek penting yaitu strategi yang dimaknai secara makro (Planned multimedia strategy) dan secara mikro (single communication medium strategy). Kedua aspek tersebut memiliki fungsi ganda yaitu sebagai berikut :

1) Menyebarluaskan pesan komunikasi yang bersifat informatif, persuasif, dan instruktif secara sistematis pada sasaran untuk memperoleh hasil yang optimal.

2) Menjembatani cultural gap, misalnya suatu program yang berasal dari suatu produk kebudayaan lain dianggap baik untuk dterapkan dan dijadikan milik kebudayaan sendiri sangat tergantung dari bagaimana strategi mengemas informasi tersebut dalam komunikasi. (Edi Suryadi, 2018:6)

Menurut R. Wayne Pace, Brent D.Peterson, dan M. Dallas Burnett menyatakan bahwa strategi komunikasi tujuan, (Effendy, 1984 : 32) yaitu To secure understanding -memastikan pesan diterima oleh komunikan, To establish acceptance - membina penerimaan pesan, To motivate action - kegiatan yang dimotivasikan. (Effendi, 2007)

Strategi komunikasi merupakan suatu cara atau taktik dasar dari rangkaian tindakan yang akan dilaksanakan untuk mencapai suatu tujuan dengan memiliki sebuah perencanaan komunikasi dengan manajemen komunikasi agar bisa mencapai tujuan yang telah ditetapkan.

Adapun konsep komunikasi yang dikemukakan oleh Harold Laswell dalam buku (Effendy, 2007a) mengatakan bahwa Cara yang baik untuk menjelaskan komunikasi ialah menjawab pertanyaan sebagai berikut: Who Says What In Which Channel To Whom With What Effect?. Paradigma Lasswell di atas menunjukkan bahwa komunikasi meliputi lima unsur. Berdasarkan paradigma Lasswell tersebut dalam buku (Effendi, 2007) strategi komunikasi harus mampu menjawab pertanyaan-pertanyaan berikut :

1. Komunikator (communicator, sender)

2. Pesan (message)

3. Media (Channel, Media)

4. Komunikan (communicate)

5. Efek ( effect) 
Dalam hal ini, strategi komunikasi sangat penting dalam mempertahankan budaya, dengan komunikasi dapat mempermudah proses pewarisan yang sudah ada dan harus di wariskan secara turun temurun. Pada penelitian ini, peneliti ingin mengetahui bagaimana strategi komunikasi yang dilakukan masyarakat dalam proses pewarisan seni lukis di kampung jelekong

\section{Komunikasi}

Istilah komunikasi berasal dari bahasa latin yaitu communis, yang artinya "sama", communication yang berarti ''membuat sama'. Komunikasi menurut paradigma Laswell komunikasi adalah proses penyampaian pesan oleh komunikator kepada komunikan melalui media yang menimbulkan efek tertentu. (Effendy, 2007)

Komunikasi tidak hanya sebatas pada konseptualisasi satu arah, melainkan juga dapat sebagai suatu proses interaksi (dua arah), atau transaksi. (Deddy Mulyana, (2012:76)

Komunikasi merupakan mekanisme untuk mensosialisasikan norma - norma budaya masyarakat, baik secara horizontal, dari suatu masyarakat kepada masyarakat lainnya ataupun secara vertikal dari suatu generasi ke generasi berikutnya.

Komunikasi memiliki empat fungsi komunikasi yang dikemukakan oleh
William I. Gorden dalam buku (Zikri Fachrul nurhadi, 2017) keempat fungsi tersebut yaitu

1. Komunikasi sosial, untuk membangun konsep, aktualisasi diri, untuk kelangsungan hidup, untuk memperoleh kebahagiaan.

2. Komunikasi ekpresif,

3. Komunikasi ritual

4. Komunikasi instrumental

\section{Kebudayaan}

Peneliti menambahkan kebudayaan pada kajian literatur karena sesuai dengan ranah penelitian. Selain itu untuk dapat mengetahui mengapa Seni Lukis dilestarikan oleh masyarakat jelekong. Kebudayaan secara sederhana dapat dipahami sebagai hasil karya, karsa, dan cipta manusia, oleh karena itu kebudayaan akan selalu berhubungan dengan manusia. Kata kebudayaan berasal dari Bahasa Sansekerta buddhayah yang merupakan kata jamak dari buddhi yang berarti budi atau akal. Kebudayaan diartikan sebagai hal-hal yang berkaitan dengan budi atau akal.

\section{Seni}

Menurut Koentjaraningrat, 1986 seni adalah bagian atau unsur dari kebudayaan. Dengan kata lain, secara simbolik, seni adalah salah satu jenis ekpresi budaya yang memiliki ciri- ciri tertentu. Jika dikatakan 
pada dasarnya budaya itu merupakan sistem simbol, maka sesungguhnya, seni itu merupakan jenis simbol khusus yang bermuatan atau mengungkapkan makna atau nilai-nilai suatu kebudayaan. Adapun menurut Merriam 1971 menegaskan bahwa aspek humanistik atau sosial budaya tidak bisa dipisahkan. (Triyanto, 2014)

\section{Seni Lukis}

Seni lukis yaitu suatu ungkapan pengalaman estetika seseorang yang dituangkan dalam bidang dwi matra (dua dimensi), dengan mengunakan media unsur rupa, yaitu garis, warna, tekstur, bentuk, dan sebagainya. Seni Lukis Menurut W. Stanley Taft dan James W. Mayer lukisan pada dasarnya merupakan sebuah gambar dua dimensi yang dilukis pada permukaan datar. (Triyanto, 2014)

\section{Pewarisan}

Budaya terlahir sebagai identitas suatu bangsa. Menurut Kodiran, 2004 Lingkungan sosial-budaya menjadi tempat dasar bagi proses pewarisan budaya serta pembentukan kepribadian dan watak pada anak yaitu melalui tindakan pembelajaran, peniruan dan penyesuaian terhadap perilaku serta tradisi masyarakatnya yang berlangsung terus-menerus berkelanjutan dan turun-temurun dari generasi ke generasi. (Sunarya, 2019)

\section{Teori Pembelajaran Sosial}

Teori pembelajaran sosial ini dikembangkan oleh Albert Bandura (1986), teori ini menerima sebagian besar dari prinsip-prinsip teori- teori belajar perilaku, tetapi memberi lebih banyak penekanan pada efek-efek dari isyaratisyarat pada perilaku, dan pada prosesproses mental internal. Dalam Teori Pembelajaran sosial telah memberi penekanan tentang bagaimana perilaku manusia dipengaruhi oleh lingkungan sekitar melalui penguatan sesuatu dan juga sebaliknya yaitu bagaimana tingkah laku dan peluang untuk diperhatikan oleh orang lain. (Janet, 2018)

\section{Metode Penelitian}

Penelitian ini menggunakan penelitian kualitatif. Penelitian ini bertujuan untuk mengetahui bagaimana strategi komunikasi masyarakat jelekong dalam mewariskan kebiasaan melukis secara turun temurun, yang tentunya dibimbing dalam teknik melukis agar lukisan yang dibuat memiliki daya tarik untuk menarik minat generasi muda untuk mempertahankan warisan seni dan budaya yang ada di kampung jelekong.

\section{Subjek dan Objek Penelitian}

Subjek dari penelitian ini adalah warga kampung jelekong yang sekaligus pemilik dari sanggar seni lukis Dwimatra 
sebagai pelaku pewarisan seni lukis yang meliputi masyarakat setempat yang memiliki kepedulian lebih terhadap kelestarian karya seni. Peneliti mengambil subjek penelitian dari masyarakat jelekong yaitu Kang Chaki selaku pemilik sanggar Dwi Matra, Mang Uyak selaku pelukis dan Mang Iyus selaku pelukis kampung jelekong.

Objek penelitiannya yaitu informasi yang akan dicari dan digali untuk melengkapi data penelitian dan diuji kebenarannya. Objek yang akan diteliti yaitu seni lukis yang sudah turun temurun menjadi ciri khas kampung wisata, kampung seni dan budaya jelekong yang sudah dijadikan sebagai sarana penghasilan masyarakat kampung jelekong.

\section{Teknik Pengumpulan Data}

Teknik pengumpulan data melalui dokumen merupakan salah satu teknik yang digunakan untuk mengumpulkan data hasil penelitian yang ditemukan dilapangan bertujuan untuk membuat dokumentasi setiap peristiwa yang berkaitan dengan informan. Teknik yang digunakan melalui wawancara, observasi.

\section{Uji Keabsahan Data}

Dalam penelitian ini kebenaran realitas data tidak bersifat tunggal, melainkan jamak dan tergantung pada kontruksi manusia itu sendiri. Kontruksi tersebut terbentuk dari hasil proses mental tiap individu yang berbeda - beda latar belakangnya. (Sugiyono, 2014)

Triangulasi dalam pengujian kredibilitas diartikan sebagai pengecekan data dari berbagai sumber dengan berbagai cara dan berbagai waktu. Dengan demikian terdapat triangulasi sumber. (Sugiyono, 2017:369) Triangulasi data terbagi menjadi tiga, diantaranya :

1. Triangulasi Sumber

Triangulasi sumber bertujuan untuk menguji kredibilitas data dengan cara mengecek data yang diperoleh melalui berbagai sumber. Dalam hal ini peneliti melakukan triangulasi sumber kepada pemilik sanggar dan pelukis, serta informan yang berasal dari masyarakat.

2. Triangulasi Teknik

Pada penelitian ini peneliti menggunakan triangulasi teknik melalui dokumentasi, peneliti merekam seluruh percakapan lalu mendiskusikan kembali dengan narasumber dengan percakapan santai.

3. Triangulasi Waktu

Waktu dapat memengaruhi kredibilitas data. Oleh karena itu, peneliti mencoba melakukan penelitian pada hari libur dan pada siang hari. Waktu tersebut adalah momen saat setiap orang libur dan 
dalam waktu santai. Selain itu, peneliti mencoba menyeseuaikan waktu wawancara dengan informan. (Sugiyono, 2017:369)

\section{HASIL PENELITIAN DAN} PEMBAHASAN

\section{Strategi Komunikasi masyarakat jelekong dalam pewarisan seni lukis}

Strategi komunikasi lain yang dilakukan masyarakat jelekong dalam upaya pewarisan seni lukis dengan membuat museum mini 3D di sekitar jalan kampung jelekong dan mengadakan workshop rutin ke sekolah - sekolah dikawasan kampung jelekong. Untuk mewariskan seni lukis diperlukan ide-ide yang kreatif agar seni lukis semakin disukai dan dicintai oleh generasi muda dan seluruh masyarakat, sebagaimana disampaikan Syahputra, 2015 tentang konsep pewarisan budaya, bahwa komunitas kultural masa kini mewarisi kebudayaan nenek moyang secara turun temurun dan terus melestarikan sebagai nilai kebudayaan kampung jelekong (Barat et al., n.d, 2018).

Kampung Jelekong telah memberikan kehidupan bagi masyarakat dari budaya seni lukis, dengan demikian manusia diharuskan untuk menjaga dan melestarikan seni lukis kampung jelekong. Manfaat mewariskan seni lukis kampung jelekong yang dirasakan yaitu untuk keberlangsungan hidup dalam menjalani kehidupan dengan melukis hasil karya lukisan yang dibuat bisa menjembatani hidup dengan penghasilan yang cukup dari hasil karya seni lukis bisa mensejahterahkan masyarakat jelekong.

Manfaat Melestarikan kebudayaan salah satunya untuk menjaga budaya dari pengaruh budaya asing, dan menjadikan ciri khas kampung Jelekong yang kaya akan seni dan kebudayaan. Dari penataan wilayah pun kita merasakan manfaat dari melestarkan seni lukis kampung jelekong menjadi tertata rapi, dan indah dinilai memiliki estetika ketika melihat sepanjang jalan kampung jelekong.

Pada proses pewarisan teknik melukis kebiasaan masyarakat didalam suatu lingkungan ditumbuh kembangkan dan dipengaruhi oleh pola pengasuhan dan pendidikan anak dalam proses pewarisan seni lukis turun temurun kepada generasi muda. Menurut Djamadin, 2004:17-19 komunikasi interpersonal adalah pesan atau informasi dari individu kepada individu lain dengan hasil penyampaian yang berupa ide dan fakta dalam konsep pemikiran (Ningsih, 2016). Oleh karena itu, komunikasi interpersonal sangat berperan penting dalam proses pewarisan seni lukis kampung jelekong saling 
mempengaruhi antara pelukis dengan generasi muda. Dalam upaya pewarisan seni lukis masyarakat jelekong menggunakan media massa sebagai alat promosi untuk memperkenalkan kesenian dan kebudayaan yang ada di kampung jelekong.

Media massa dipandang membawa pengaruh tertentu bagi masyarakatnya, dengan membawa kesadaran dan ide-ide baru, mengajarkan keterampilan, memperkenalkan kebudayaan secara cepat didalam lingkungan masyarakat. Pelukis jelekong memperkenalkan kesenian seni lukis melalui media massa seperti sosial media dan website. Hal ini menimbulkan terjadinya hubungan timbal balik yang saling mempengaruhi antara media massa dan budaya masyarakat. Media massa membawa pengaruh tertentu, seperti dalam proses pewarisan kebudayaan aktivitas yang dilakukan dapat tersebar secara cepat sebagai informasi terhadap khalayak. Upaya yang dilakukan masyarakat jelekong dapat mempermudah generasi muda untuk memanfaatkan kecanggihan teknologi mencari dan menambah pengetahuan baru dalam mempelajari teknik dasar melukis. Hal ini terlihat bagaimana media massa menjadi sumber utama dalam proses pewarisan nilai-nilai sosial budaya dari suatu generasi ke generasi berikutnya.

\section{Peranan pelukis senior dalam mewariskan seni lukis}

Dalam teori pembelajaran sosial menjelaskan bahwa perilaku manusia dapat dipengaruhi oleh lingkungan sekitar melalui proses meniru sesuatu yaitu bagaimana tingkah laku yang diamati dan ditiru setelah memperhatikan perilaku orang lain. Hal itu menegaskan bahwa dalam upaya pewarisan seni lukis Pembelajaran yang terjadi ketika seseorang melihat dan meniru perilaku orang lain.

Teknik yang diajarkan di kampung seni lukis jelekong itu tidak seperti belajar di sekolah formal tetapi lukisan jelekong dilakukan secara praktek yang pertama diajarkan yaitu mengajarkan teknik dasar melukis, dengan mengenal warna, bahan, cat, kanvas. Cara menerapkan nya membuat sketsa terlebih dahulu, harus mengetahui titik cahaya nya dimana, dan mengetahui gradiasi warna. Setelah mengetahui teknik dasar melukis, pelukis junior membuat gambar bebas tergantung keinginan. Setelah selesai menggambar sketsa dasar, pelukis senior baru mengarahkan dan menjelaskan bagaimana teknik menggambar supaya lukisan terlihat lebih hidup. 
Dengan mempelajari teknik dasar melukis upaya pewarisan budaya pada pelukis junior memerlukan waktu selama lima bulan untuk mengusai teknik melukis seperti pelukis seniornya, tetapi kembali kepada motivasi murid yang muncul dari dalam diri, serta para orang tua yang memiliki peran vital dalam proses pewarisan nilai-nilai kebudayaan akan mempercepat kemampuan melukis pada pelukis junior.

\section{Hambatan masyarakat jelekong pewarisan seni lukis}

Hambatan internal yang terjadi pada masyarakat dalam proses pewarisan yaitu banyaknya generasi muda yang menolak untuk mewarisi teknik melukis, dengan alasan melukis tidak mudah dalam menggambar, membutuhkan waktu dan motivasi yang baik untuk memiliki kemampuan melukis. Seperti ada pepatah "buah jatuh tidak akan jauh dari pohonya" begitupun dalam melukis jika tidak ada keturunan dan motivasi yang kuat maka akan susah untuk mewariskan seni lukis kepada generasi muda. Begitupun sebaliknya masyarakat yang menempuh pendidikan formal tetapi mempunyai motivasi yang sangat tinggi tetapi tidak memiliki pewarisan keturunan, sangat mudah untuk mewariskan seni lukis. Hal tersebut memungkinkan hambatan faktor internal sangat berperan penting dalam pewarisan seni lukis kampung jelekong.

Hambatan eksternal yang terjadi didalam proses pewarisan seni lukis yaitu kecanggihan teknologi yang membuat lukisan jelekong kurang banyak diminati oleh generasi muda, dalam teknik melukis yang rumit generasi muda lebih memilih bermain gadget. Hal tersebut yang dirasakan oleh pelukis senior yang kesulitan dalam pewarisan teknik melukis dan mengatakan hambatan pengaruh teknologi tidak bisa dipungkiri dengan perkembangan jaman saat ini, namun didalam gadget ada dampak positif dan negatif.

Salah satu manfaat gadget bisa mengakses informasi-informasi kebudayaan dengan mudah. Banyak wisatawan dari luar yang berkunjung ke kampung jelekong dengan alasan mengetahui informasi budaya kampung jelekong melalui internet dan sosial media. Faktor lingkungan dinilai tidak terlalu berpengaruh jika motivasi generasi muda tinggi untuk belajar melukis Maka akan tetap terfokus pada keinginannya tanpa disadari ada hambatan tersebut.

\section{Simpulan}

Strategi Komunikasi dalam Pewarisan keahlian melukis di lingkungan Jelekong 
merupakan usaha turun temurun yang dilakukan oleh masyarakat untuk menjaga kesinambungan hidup, didukung juga oleh lingkungan jelekong yang kaya akan seni dan budaya yang menjadikan kampung jelekong disebut kampung seniman. Masyarakat jelekong membangun sanggar dan membuat tempat wisata mini 3D yang menyuguhkan hasil tangan pelukis pelukis jelekong yang bergambar 3D sehingga bagus sekali untuk spot foto dan untuk edukasi dalam melakukan teknik melukis dapat menarik minat dan motivasi agar memudahkan para wisatawan dan generasi muda untuk belajar melukis.

Pelukis jelekong mengenalkan generasi muda untuk mencintai warisan peninggalan dan melakukan pewarisan dalam menurunkan kemampuannya kepada generasi muda supaya lukisan jelekong tetap bertahan, teknik yang diajarkan pelukis senior dengan teknik dasar mengenal berbagai tema lukisan, dan mengenal bahan.
Terdapat dua faktor hambatan yang terjadi dalam proses pewarisan seni lukis yaitu faktor internal dan external. Hambatan internal merupakan hambatan yang datang dari diri individu, contohnya seperti kurangnya motivasi yang timbul dalam diri untuk mewariskan teknik melukis, dan individu berpendapat bahwa melukis itu sangat sulit dilakukan banyak teknik dalam melukis dan ketekunan yang harus dimiliki calon pelukis, melukis sama dengan berkarya apa yang dipikirkan, diungkapkan dalam kanvas. Dengan motivasi yang timbul dalam individu sangat berperan penting dalam upaya pewarisan seni lukis jelekong. Sedangkan faktor external faktor yang datang dalam lingkungan, contohnya hambatan yang terjadi pada kesejahteraan pelukis jelekong menurunnya peminat seni lukis membuat sebagian pelukis jelekong beralih profesi, sedangkan pelukis jelekong menggantungkan hidupnya pada hasil karya lukisan. 


\section{Daftar Pustaka}

Buku

Barat, D. J., Sadono, S., Nugroho, C., \& Nasionalita, K. (n.d.). Pewarisan Seni Wayang Golek. 150-163.

Edi Suryadi. (2018). STRATEGI KOMUNIKASI (Deni Darmawan (Ed.); Rosdakarya).

Effendy, O. U. (2007a). Ilmu Komunikasi Teori dan Praktek. Remaja Rosdakarya.

Effendy, O. U. (2007b). Ilmu Komunikasi Teori dan Praktek (T. Surjaman (Ed.); 1st-20th ed.).

J.R.Raco. (2010). METODE PENELITIAN KUALITATIF jenis, karakteristik dan keunggulannya ( penyelia Arita (Ed.)).

Janet, H. R. (2018). Dalam Proses Mengajar di sekolah. 186-202.
Kepala, L., Seni, J., Antropologi, M., Sekaran, K., \& Semarang, G. (2014). Pendidikan seni berbasis budaya. VIII(1).

Ningsih, L. J. (2016). STRATEGI KOMUNIKASI INTERPERSONAL DALAM SAMARINDA. 4(3), 471481.

Prof. Deddy Mulyana, MA, Ph.D. (2012). suatu pengantar ilmu komunikasi. Rosdakarya.

STANLEY J. BARAN. (2012). Pengantar Komunikasi Massa (Y. S. HAYATI (Ed.); ERLANGGA). Sunarya, A. (2019). Indonesian Journal of Anthropology Pewarisan Keahlian Mendalang pada Keluarga Dalang Wayang Golek Abah Sunarya. 4(September), 130140.

zikri Fachrul nurhadi. (2017). Teori Komunikasi Kontemporer (Suwito (Ed.)). kencana. 